\title{
KONVERGENSI HARGA PANGAN POKOK ANTAR WILAYAH DI INDONESIA
}

\author{
Emilia Khristina Kiha ${ }^{1}$ dan Wiwiek Rindayati ${ }^{2}$ \\ ${ }^{1}$ Staf pengajar STIE Kriswina Sumba \\ ${ }^{2}$ Staf Pengajar FEM IPB
}

Artikel diterima Januari 2013

Artikel disetujui untuk dipublikasikan Juli 2013

\begin{abstract}
In Indonesia, the increase in food prices usually results in the rise in the inflation rate. To cope with this problem, a better food distribution among regionsis absolutely required. This study aimed to describe the dynamics of food prices, to test the convergence level of food prices and to analyze the factors that influence the changes in food prices between regions in Indonesia. The data used were obtained from the Central Agency of Statistics and the Ministry of Agriculture from 2002 to 2010. The method used was analysis of dynamic panel data (First Difference-Generalized Methode Moment/FDGMM). The results of the study showed that all commodities of food prices were convergent, sugar at the highest level and rice at the lowest, while the factors that influence changes in food prices were production rate, Gross Domestic Product (GDP) and population.
\end{abstract}

Keywords: Convergence, Food Prices, GMM Panel Data

\section{PENDAHULUAN}

Pangan adalah kebutuhan pokok sekaligus menjadi aspek yang esensial bagi kehidupan manusia, sebagaimana termuat dalam Undang-undang Nomor 7 Tahun 1996 tentang Pangan yang dirumuskan sebagai usaha mewujudkan ketersediaan pangan bagi seluruh rumah tangga, dalam jumlah yang cukup, mutu dan gizi yang layak, aman dikonsumsi, merata serta terjangkau oleh setiap individu. Kecukupan pangan menentukan kualitas sumberdaya manusia dan ketahanan bangsa. Namun kenyataannya Indonesia belum mencapai ketahanan pangan. Ketergantungan pangan masih sangat tinggi, dimana dari pengeluaran rata-rata rakyat Indonesia untuk makanan sebesar 50,62\% pada tahun 2009.

Produk pangan pada umumnya mengikuti pola produksi musiman, sedangkan kebutuhan pangan harus dipenuhi sepanjang tahun. Selain itu produk pertanian pada umumnya cepat rusak (perisable). Dalam kondisi demikian maka aspek pengolahan dan penyimpanan menjadi hal penting dalam upaya penyediaan pangan secara kontinyu. Di Indonesia, produksi pangan tersebar menurut agro ekosistem dan geografinya, sedangkan lokasi konsumen tersebar di seluruh pelosok tanah air, baik yang tinggal di daerah perkotaan maupun perdesaan. Dengan demikian aspek transportasi dan distribusi pangan menjadi sangat vital dalam rangka penyediaan pangan yang merata bagi seluruh penduduk Indonesia. Kurang meratanya penyediaan pangan bagi masyarakat menjadi pemicu kenaikan harga pangan.

Pemicu kenaikan harga pangan disebabkan dari kinerja pasokan yang sedikit terganggu, meskipun pemerintah berkali-kali membantah bahwa pasokan pangan aman dan terkendali. Fakta di lapangan menunjukkan bahwa sistem produksi dan sistem distribusi beberapa 
pangan terganggu karena kualitas sarana dan prasarana transportasi banyak yang rusak. Rusaknya jalan di beberapa ruas di Pantai Utara Jawa, buruknya jalan Lintas Tengah dan Lintas Timur di Sumatera, sebagai dua poros utama jalur distribusi pangan. Sementara aktivitas ekonomi di Pulau Jawa dan Sumatera sebesar 84\% merupakan penyumbang terbesar terhadap kinerja ekonomi nasional atau Produk Domestik Bruto (PDB) Indonesia. Betapa besarnya dampak yang ditimbulkan apabila sarana infrastruktur di Jawa dan Sumatera terganggu. Dimana akibat kurang pasokan dan sistem distribusi pangan yang terganggu menyebabkan harga pangan meningkat dan berdampak pada kenaikan tingkat inflasiyang bukan hanya ditanggung konsumen di perkotaan, tetapi juga harus ditanggung oleh petani di pelosok perdesaan. Kenaikan harga pangan ini sedikit sekali yang dapat dinikmati petani karena persentase kenaikan harga di tingkat konsumen jauh lebih besar dibandingkan dengan persentase kenaikan harga di tingkat produsen.

Tingkat inflasi dari beberapa kota di Indonesia selalu berbeda dimana pada bulan Agustus 2011 tingkat inflasi sebesar 0,93\% dengan Indeks Harga Konsumen (IHK) sebesar 128,54. Dari 66 kota IHK, seluruh kota mengalami inflasi. Inflasi tertinggi terjadi di Pangkal Pinang 3,05\% dengan IHK 140,49 dan terendah terjadi di Denpasar $0,02 \%$ dengan IHK 129,38.

Meskipun dilihat dari 66 kota di Indonesia tingkat inflasi yang terjadi selalu berbeda pada setiap daerah tetapi secara nasional tingkat inflasi mempunyai kecenderungan untuk naik setiap bulannya yang dapat dilihat dari tingkat inflasi nasional dari bulan Juli 2010-Juli 2011.

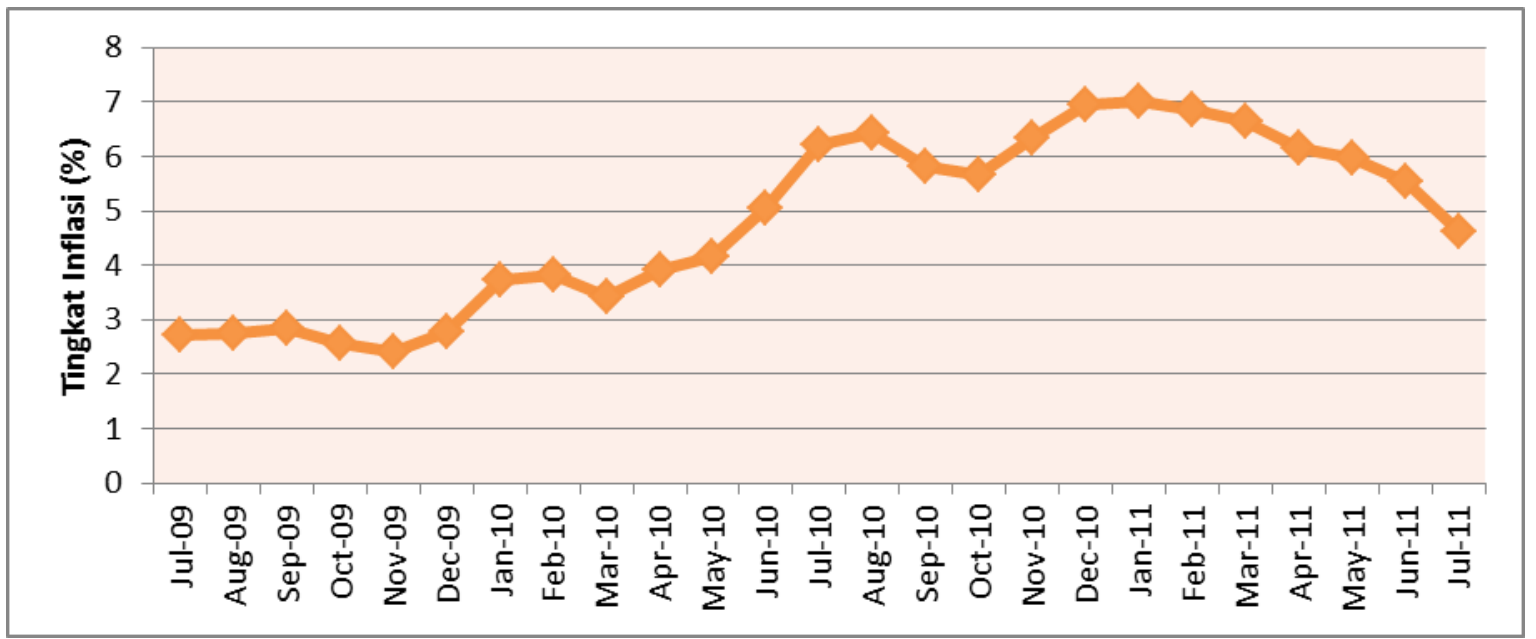

Gambar 1 Tingkat Inflasi Indonesia Periode Juli 2009 - Juli 2011

Kenaikan tingkat inflasi disebabkan karena adanya perubahan harga pada barang bergejolak (volatile food), inflasi inti (core inflation) dan harga yang diatur pemerintah (administered prices). Secara historis terlihat bahwa sumbangan barang bergejolak (volatile foods) terhadap inflasi di Indonesia sangat signifikan dan menduduki urutan pertama setelah inflasi inti (core inflation). Bahkan porsi sumbangannya cenderung meningkat dari
3,95\% pada tahun 2009 menjadi $17,74 \%$ pada tahun 2010, sementara porsi sumbangan inflasi inti (core inflation) dan harga yang diatur pemerintah (administered prices) hanya sebesar $4,28 \%$ dan $5,40 \%$. Hal menarik selanjutnya adalah fakta bahwa perubahan harga kelompok volatile foods sangat bergejolak, menyebabkan tingkat inflasinya menjadi lebih berfluktuasi seperti terlihat pada Gambar 2. 


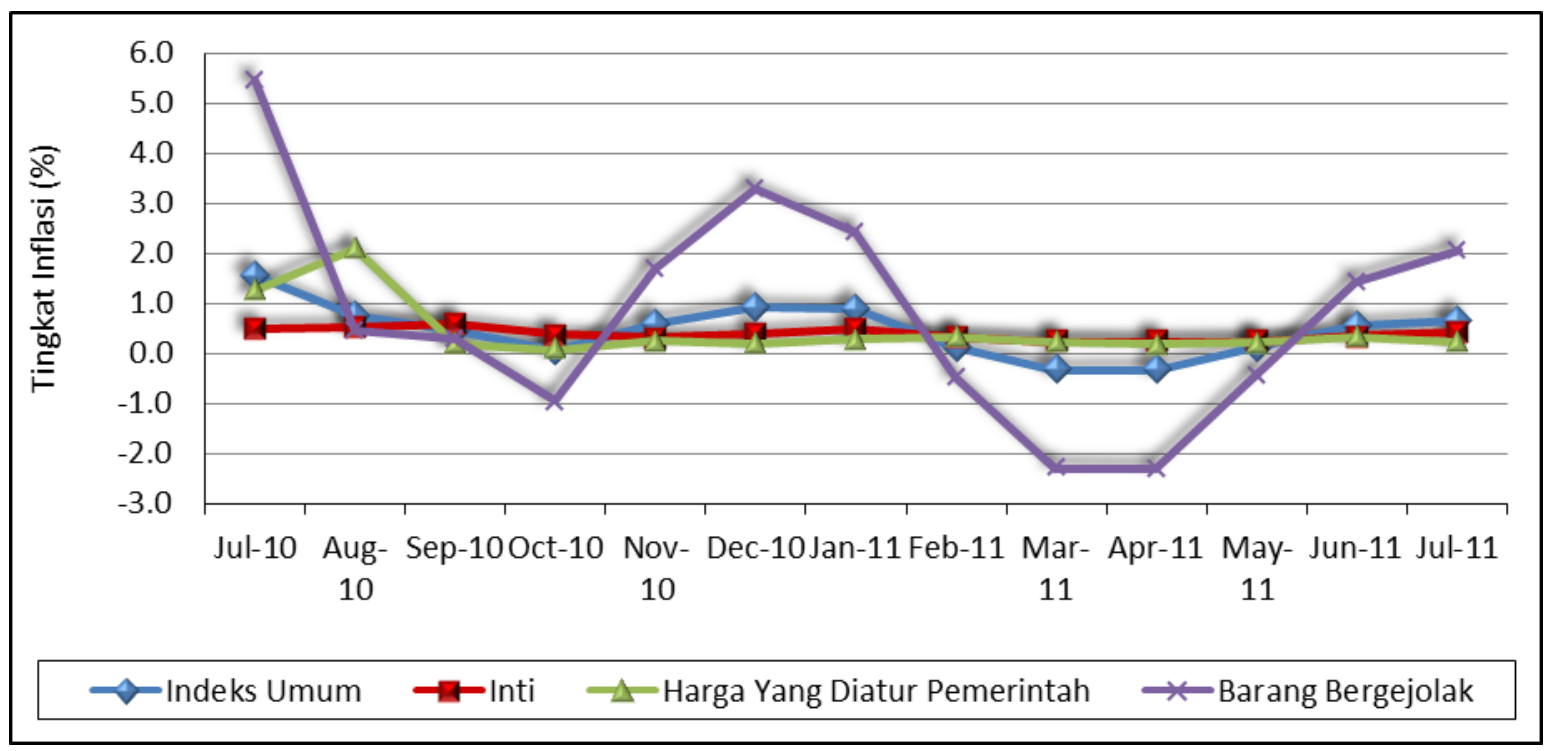

Gambar 2. Perkembangan Laju Inflasi Indonesia Periode Juli 2010 - Juli 2011

Namun, mengingat jumlah komoditas yang digunakan untuk perhitungan inflasi kelompok volatile foods di Indonesia saat ini terdiri atas 61 komoditas maka penelitian ini menfokuskan pada beberapakomoditas pangan yang memiliki peran besar dalam pembentukan inflasi secara nasional. Lebih detil, inflasi kelompok volatile foods tersebut didominasi oleh beberapa komoditas saja. Dan upaya untuk mengendalikan atau mengurangi volatilitas harga komoditas pangan jika dapat diketahui faktor-faktor yang mempengaruhi pembentukan harga dan penyebab volatilitas tersebut. Untuk itu dari Tabel 1 memberikan informasi tentang sumbangan inflasi dari komoditas yang akan dijadikan sampel, dimana pengambilan sampel ini dilandasi oleh bobot dan sumbangan terbesar terhadap inflasi.

Tabel 1 Sumbangan Inflasi dari Kelompok Barang yang Bergejolak (Volatile Foods)

\begin{tabular}{|clcccccc|}
\hline \multirow{2}{*}{ No } & Nama Komoditi & \multicolumn{3}{c}{2007} & \multicolumn{2}{c}{2009} & \multicolumn{2}{c|}{2011} \\
\cline { 3 - 7 } & & $\begin{array}{c}\text { Bobot } \\
(\%)\end{array}$ & Sumbangan & $\begin{array}{c}\text { Bobot } \\
(\%)\end{array}$ & Sumbangan & $\begin{array}{c}\text { Bobot } \\
(\%)\end{array}$ & Sumbangan \\
\hline 1 & Beras & 7,22 & 0,589 & 6,14 & 0,737 & 5,06 & 0,885 \\
2 & Daging Ayam Ras & 1,42 & 0,220 & 1,48 & 0,373 & 1,54 & 0,527 \\
3 & Daging Sapi & 0,67 & 0,110 & 0.70 & 0,103 & 0,82 & 0,096 \\
4 & Bawang merah & 0,52 & 0,826 & 0,52 & 0,556 & 0,52 & 0,286 \\
5 & Cabe Merah & 0,24 & 0,137 & 0,20 & 0,130 & 0,21 & 0,129 \\
6 & Minyak Goreng & 1,56 & 0,538 & 1,41 & 0,672 & 1,27 & 0,806 \\
7 & Gula Pasir & 0,15 & 0,151 & 0,11 & 0,120 & 0,08 & 0,121 \\
8 & Telur Ayam Ras & 0,80 & 0,163 & 0,80 & 0,263 & 0,81 & 0,364 \\
9 & Kacang Kedelai & 0,67 & 0,093 & 0,49 & 0,138 & 0,52 & 0,184 \\
\hline
\end{tabular}

Setelah mempertimbangkan bobot dan sumbangan inflasi dari komoditas pangan pokok maka dalam penelitian ini diambil tiga komoditas untuk dibahas secara lebih mendalam, yaitu beras, minyak goreng dan gula pasir antar propinsi di Indonesia karena inflasi daerah mempengaruhi $78 \%$ terhadap inflasi nasional. Sehingga yang menjadi permasalahan utama yang dibahas dalam penelitian ini adalah bagaimana pergeseran pergerakkan harga apakah konvergen atau divergen dari tiga pangan pokok antar wilayah di Indonesia dan faktor-faktor yang mempengaruhinya. 


\section{TINJAUAN TEORITIS DAN PERUMUSAN HIPOTESIS}

\section{Konvergensi}

Arti kata konvergensi adalah keadaan menuju suatu titik pertemuan. Mengkonvergensikan artinya mengarahkan pada suatu titik pertemuan. Bila dikaitkan dengan harga pangan pokok, maka yang dimaksud konvergensi harga pangan adalah bahwa harga-harga pangan pokok apakah akan mengarah pada satu titik atau satu harga (konvergen) dan apabila tidak mengarah pada satu titik harga maka disebut divergen. Teori konvergensi menyatakan bahwa tingkat kemakmuran yang dialami oleh negara-negara maju dan negaranegara berkembang pada suatu saat akan konvergen (bertemu di satu titik). Disebutkan bahwa akan terjadi catching up effect, yaitu kondisi ketika negaranegara berkembang berhasil "menangkap" negara-negara maju. Teori ini didasarkan pada asumsi bahwa negara-negara maju akan mengalami kondisi steady state, yaitu negara yang tingkat pendapatannya tidak dapat meningkat lagi. Hal ini bisa terjadi karena seluruh biaya produksi sudah tertutupi oleh investasi yang ada, sehingga tambahan tabungan di negara tersebut tidak dapat dijadikan tambahan investasi. Tidak ada tambahan investasi berarti tidak ada tambahan pendapatan. Sementara itu negara-negara berkembang memiliki tingkat investasi dibawah biaya produksi, sehingga tambahan tabungan di negara tersebut akan dijadikan tambahan investasi dan akhirnya menambah pendapatan negara tersebut. Jadi, sementara negara-negara maju "diam", negara-negara berkembang terus "mengejar", sehingga pada suatu saat negara-negara maju pasti akan "tertangkap" oleh negara-negara berkembang (Quah 1995).

Menurut Barro dan Salai-Martin (1991) konvergensi harga hadir ketika adanya perbedaan harga yang berarti antar wilayah dan antar waktu. Dimana dengan adanya perbedaan harga maka pemerintah akan melalukan kebijakankebijakan sehingga harga antar waktu maupun antar daerah bisa di kurangi atau konvergensi harga bisa terjadi. Dengan adanya harga yang konvergen itu berarti kebijakan pemerintah telah berhasil.

\section{Pangan Pokok}

Pangan merupakan komoditas penting dan strategis karena pangan merupakan kebutuhan pokok manusia yang pemenuhannya menjadi hak asasi setiap rakyat Indonesia sebagaimana dinyatakan dalam UU No. 7 Tahun 1996 tentang Pangan. Oleh karena itu terpenuhinya kebutuhan pangan di dalam suatu negara merupakan hal yang mutlak harus dipenuhi. Selain itu pangan juga memegang peranan penting dan strategis di Indonesia berdasarkan pada pengaruh yang dimilikinya baik secara sosial, ekonomi dan politik.

Ketahanan pangan bagi suatu negara merupakan hal yang sangat penting, terutama bagi negara yang mempunyai penduduk sangat banyak seperti Indonesia. Jumlah penduduk Indonesia diperkirakan mencapai 220 juta jiwa pada tahun 2020 dan diproyeksikan 270 juta jiwa pada tahun 2025. Pengalaman sejarah pembangunan Indonesia menunjukkan bahwa masalah ketahanan pangan sangat erat kaitannya dengan stabilitas ekonomi (khususnya inflasi), biaya produksi ekonomi agregat (biaya hidup) dan stabilitas politik nasional. Oleh karena itu, ketahanan pangan menjadi syarat mutlak bagi penyelenggaraan pembangunan nasional. Kecukupan pangan menentukan kualitas sumber daya manusia dan ketahanan bangsa. Oleh karena itu untuk membentuk manusia Indonesia yang berkualitas, pangan harus tersedia setiap saat dalam jumlah yang cukup, merata, aman, bermutu, bergizi, beragam, dan dengan harga yang terjangkau oleh daya beli masyarakat (Sulastiri 2008). 
Timmer (2008) menekankan bahwa pencapaian dan keberhasilan memelihara ketahanan pangan, baik ditingkat rumah tangga maupun tingkat nasional, akan menghasilkan penurunan kemiskinan dan juga kelaparan. Pemerintah yang berhasil adalah pemerintah yang mampu mendukung ketahanan pangan untuk warga negaranya. Penurunaan kemiskinan itu sendiri akan berhasil hanya jika ada kesanggupan politis dasar untuk menciptakan pertumbuhan ekonomi yang cepat dan juga merata distribusinya. Percepatan pertumbuhan ekonomi membutuhkan kondisi yang kondusif seperti kestabilan makroekonomi, termasuk harga bahan pangan yang relatif stabil, kebijakan perdagangan terbuka untuk barang dan jasa, ekonomi pasar yang kompetitif.

\section{Volatilitas Harga Pasar}

Faktor-faktor yang mempengaruhi sisi penawaran komoditas pangan atau pertanian cenderung sulit untuk dikontrol. Menurut Suparmoko (1997) yang mempengaruhi penawaran suatu produk adalah jumlah barang yang ditawarkan (produksi), harga barang, jumlah faktor produksi (input) yang tersedia, keadaan alam, pajak dan teknologi. Sementara menurut Raharja dan Mandala (2002) meliputi harga barang, harga barang lain berupa barang substitusi atau komplemen, biaya produksi, teknologi produksi, jumlah pedagang atau penjual, tujuan perusahaan dan kebijakan pemerintah. Berbeda dengan Soekartawi (2002) bahwa yang mempengaruhi penawaran produk pertanian meliputi harapan konsumen dan elastisitas produksi. Upaya peningkatan produksi pertanian tidak dapat dilakukan secara instan karena terkait dengan infrastruktur, luas lahan, teknologi dan keahlian yang memerlukan investasi dan penanganan jangka panjang (Prastowo, 2008). Sementara faktor distribusi dapat dipengaruhi secara lebih cepat dan jumlah investasi yang dibutuhkan relatif lebih kecil. Walaupun keberhasilan panen sangat dipengaruhi oleh kondisi musim atau cuaca yang sifatnya uncontrolable, pengaruh pola tanam terhadap perkembangan harga komoditas pertanian di Amerika Serikat terlihat sangat dominan. Terdapat pola cyclical yang sistematis antara pola tanam dan variance harga komoditas. Variance harga membesar pada saat musim tanam dan mengecil pada saat musim panen. Sementara keberadaan teknologi penyimpanan atas produk pertanian, khususnya untuk produk yang mudah busuk/ basi (durable products), akan mengurangi tekanan fluktutasi harga dari komoditas tersebut.

Tekanan sisi permintaan juga berpotensi meningkatkan harga komoditas pertanian walaupun derajatnya relatif rendah dibanding tekanan dari sisi penawaran. Sumber utama peningkatan permintaan komoditas pangan adalah harga komoditas, pendapatan konsumen, harga yang berhubungan (komplementer dan substitusi), selera konsumen (Salvator, 1996), jumlah penduduk, perkiraan harga periode mendatang, upaya penjualana berupa promosi (Raharja dan Mandala, 2002), kemiskinan (Siregar, 2009) dan elastisitas permintaan yaitu harga, pendapatan serta silang (Soekartawi, 2002). Sementara Borensztein et al. (1994) berpendapat bahwa permintaan komoditas pertanian lebih dipengaruhi oleh aktivitas perekonomian (economic growth).

Pada rezim perdagangan bebas, harga komoditas domestik akan bergerak mengikuti harga internasional, sehingga akan lebih volatile jika pemerintah tidak melakukan intervensi. Banyak negara reluctant untuk bergerak ke arah perdagangan bebas secara penuh untuk komoditas pangan atau pertanian karena komoditas tersebut merupakan komoditas penting yang dapat menimbulkan instabilitas politik (Dawe, 2001).

Teori Cobweb (sarang laba-laba) terjadi pada produk pertanian karena 
berfluktuasi pada musim ke musim, reaksi terlambat (time lag) dari produsen terhadap harga dan undurable goods. Teori Cobweb menjelaskan siklus harga dan produksi yang naik turun dalam jangka waktu tertentu, yang pada dasarnya dapat dibedakan menjadi: (1) siklus dengan fluktuasi yang jaraknya tetap; (2) Siklus yang menuju titik keseimbangan; dan (3) Siklus yang menjauhi titik keseimbangan. Kondisi keseimbangan yang terjadi di pasar tentunya menjadi relatif tidak stabil apabila ada kekuatan-kekuatan yang mendorong harga dan jumlah barang atau komoditas yang pada akhirnya akan mencapai keseimbangan baru. Berkaitan dengan aspek ini, di pasar ada kemungkinan akan terjadi kelebihan barang atau komoditas yang ditawarkan (surplus) dan kekurangan barang atau komoditas yang ditawarkan atau kelebihan barang atau komoditas yang diminta (shortage).

\section{Faktor-faktor yang Mempengaruhi Harga Pangan Pokok}

\subsection{Jumlah Produksi dari Sisi Penawaran}

Studi empiris yang dilakukan oleh Deaton dan Laroque (1992), Chambersdan Bailey (1996) dan Tomek (2000) menyimpulkan dua faktor yangsangat berpengaruh terhadap pembentukan harga komoditas pangan/ pertanian, yakni faktorproduksi/ panen (harvest disturbance) dan perilaku penyimpanan (storagel inventory behavior). Walaupun keberhasilan panen sangat dipengaruhi oleh kondisi musim/ cuaca yang sifatnya uncontrolable, pengaruh pola tanam terhadap perkembangan hargakomoditas pertanian di Amerika Serikat terlihat sangat dominan. Terdapat pola cyclicalyang sistematis antara pola tanam dan variance harga komoditas. Variance hargamembesar pada saat musim tanam dan mengecil pada saat musim panen. Sementarakeberadaan teknologi penyimpanan atas produk pertanian, khususnya untuk produk yangmudah busuk/basi (durable products), akan mengurangi tekanan fluktutasi harga dari komoditas tersebut.

\subsection{Pendapatan Domestik Regional Bruto (PDRB) dari sisi Permintaan}

Sumber utama peningkatan permintaan komoditas pangan adalah peningkatan jumlah penduduk dan pendapatan (Tomek 2000). Namun untuk negara maju, income effect kepada permintaan komoditas pertanian relatif kecil bila dibandingkan dengan negara berkembang yang mempunyai income elasticity lebih tinggi. Sementara Borensztein et al. (1994)berpendapat bahwa permintaan komoditas pertanian lebih dipengaruhi oleh aktivitas perekonomian (economic growth). Membaiknya pertumbuhan ekonomi akan meningkatkan pendapatan masyarakat yang selanjutnya mendorong konsumsi. Kondisi ini memacu sektor industri untuk meningkatkan produksi makanan sehingga permintaan komoditas pertanian sebagai bahan baku meningkat.

\subsection{Jumlah Penduduk dari sisi Permintaan \\ Pertumbuhan ekonomi China dan} India, kedua negara dengan jumlah penduduk terbesar, menyebabkan peningkatan permintaan yang luar biasa terhadap bahan makanan sehingga akan menyebabkan kenaikan pada harga pangan (Hasan, 2008). Hal ini senada dengan hasil penelitian Siregar (2009) bahwa semakin bertambahnya penduduk dunia, terutama di negara-negara berkembang di Asia yang menyebabkan semakin tingginya kebutuhan atau permintaan akan komoditas-komoditas pertanian, sehingga mendorong hargaharga komoditas tersebut untuk meningkat.

\subsection{Infrastruktur dari sisi Penawaran}

Beberapa teori pertumbuhan ekonomi menjelaskan arti pentingnya 
infrastruktur terhadap pembangunan regional, karena akan menjadi determinan dalam pembangunan sistem pertumbuhan di tingkat lokal dan bagaimana kemudian jalur pembangunan akan terbentuk. Beberapa studi telah diukur pengaruh kualitas jalan pada biaya transportasi dan integrasi pasar. Loveridge (1991) menunjukkan bahwa perbaikan proyek jalan di barat daya Rwanda mengurangi perbedaan harga antara dua pasar dan meningkatkan korelasi harga mereka dari waktu ke waktu. Minten dan Kyle (1999) menemukan bahwa biaya transportasi dua kali lebih tinggi di jalan buruk dibandingkan dengan jalan beraspal di Zaire. Biaya tinggi transportasi di jalan buruk mengakibatkan harga yang lebih rendah yang di terima petani dalam menjual hasil panen mereka.

\section{METODE PENELITIAN}

Penelitian ini menggunakan data sekunder time series dari tahun 20012010 dan cross section dari 26 propinsi di Indonesia (data panel). Data yang digunakan berasal dari Badan Pusat Statistik (BPS), Kementerian Pertanian dan Kementerian Pekerjaan Umum.

Metode analisis dalam konvergensi harga pangan pokok antar wilayah di Indonesia menggunakan panel data dinamis First-Differences GMM (FDGMM) dan System GMM. Sedangkan faktor-faktor yang mempengaruhi harga pangan pokok antar wilayah di Indonesia menggunakan analisis data panel statis.

Spesifikasi Model konvergensi harga pangan pokok menggunakan variable dependen harga pangan pokok, untuk melihat konvergensi dari tahun 2001-2010.

Model penelitian tersebut adalah:

$$
\begin{aligned}
p_{i t}= & (1-\beta) \ln p_{i t-1}+\beta_{1} \text { produksi } \\
& +\beta_{2} \text { PDRB }+\beta_{3} \text { penduduk } \\
& +\beta_{4} \text { jalan }+ \text { zit.................. (3.1) }
\end{aligned}
$$

Dimana $p_{i t}$ dalam masing-masing model adalah variabel dependen yaitu: harga eceran beras, daging ayam, daging sapi, bawang merah, cabe merah, minyak goreng, gula pasir, telur ayam ras dan kacang kedelai di tingkat konsumen. Proses konvergensi terjadi apabila koefisien dari $(1-\alpha)$ kurang dari satu, dengan tingkat konvergensi dinyatakan sebagai - $\ln (\alpha)$.Adanya lag variabel dependen $\left(p_{i t-1}\right)$ pada ruas kanan menunjukkan bahwa model yang digunakan adalah model dinamis. Data tersebut diolah dengan menggunakan program Stata v.10.

Faktor-faktor yang mempengaruhi harga pangan pokok menggunakan model dengan variabel dependen yang berbeda namun variabel independennya yang sama. Model penelitian dinyatakan dengan:

$$
\begin{array}{ll}
y_{\text {it }} & =y_{i t-1}+\quad \beta_{1} \text { prod } \\
& + \\
& \beta_{2} \text { PDRB }+\beta_{3} \text { pendk }+ \\
& \beta_{4} \text { jalan } \\
& +\varepsilon_{\mathrm{it}} \ldots .(3.2)
\end{array}
$$

Dimana :

$$
\begin{aligned}
y_{i t}= & \text { harga eceran } 3 \text { pangan pokok } \\
& \text { yaitu beras, minyak goreng, } \\
& \text { gula pasir (dalam rupiah) } \\
y_{i t-1}= & \text { harga eceran tahun } \\
& \text { sebelumnya dari } 3 \text { pangan } \\
& \text { pokok (dalam rupiah) } \\
P D R B= & \text { Pendapatan Domestik } \\
& \begin{array}{l}
\text { Regional Bruto (dalam } \\
\text { rupiah) }
\end{array}
\end{aligned}
$$
$P D R B=$ Pendapatan Domestik Regional Bruto (dalam rupiah)

Prod = jumlah produksi (dalam ton)

pendk = jumlah penduduk (dalam jiwa)

jalan $=$ panjang jalan (dalam kilo meter)

$\alpha_{i}$ dan $\beta_{i} \quad=$ Koefisien Regresi

$\begin{array}{ll}\varepsilon_{\mathrm{it}} & =\text { Error Term } \\ i & =26 \text { provinsi di Indonesia }\end{array}$ (kecuali 6 propinsi yang baru mekar)

$t=$ tahun penelitian, yaitu dari $2001-2010$. 


\section{HASIL DAN PEMBAHASAN}

1. Dinamika Perubahan Harga Pangan Antar Wilayah dan Antar Waktu di Indonesia

Dinamika harga pangan pokok mencakup komoditi beras, minyak goreng dan gula pasir. Harga beras bila dilihat antar wilayah di Indonesia selalu berbeda di setiap propinsi dimana harga rata-rata tertinggi dari tahun $2002-2010$ di Jayapura karena disebabkan sebagian petani di daerah produksi mengalami gagal panen karena faktor cuaca yang buruk sehingga hasil yang didapat juga berkurang dan pasokan sembilan bahan kebutuhan pokok (sembako), sebagian besar didatangkan dari luar sehingga harga juga mengikuti harga dari luar. Sedangkan harga rata-rata beras terendah di Makasar yang sebabkan oleh banyaknya pasokan dari daerah produsen dan rata-rata daerah produsen di Sulawesi Selatan sedang panen serta rendahnya kualitas beras pengaruh musim hujan yang berkepanjangan. Jika dibandingkan dengan rata-rata nasional, maka harga komoditi beras yang berada di atas ratarata nasional sebesar $42.31 \%$. Sedangkan harga komoditi beras yang berada di bawah rata-rata nasional sebesar 57.69\% (Gambar 3).

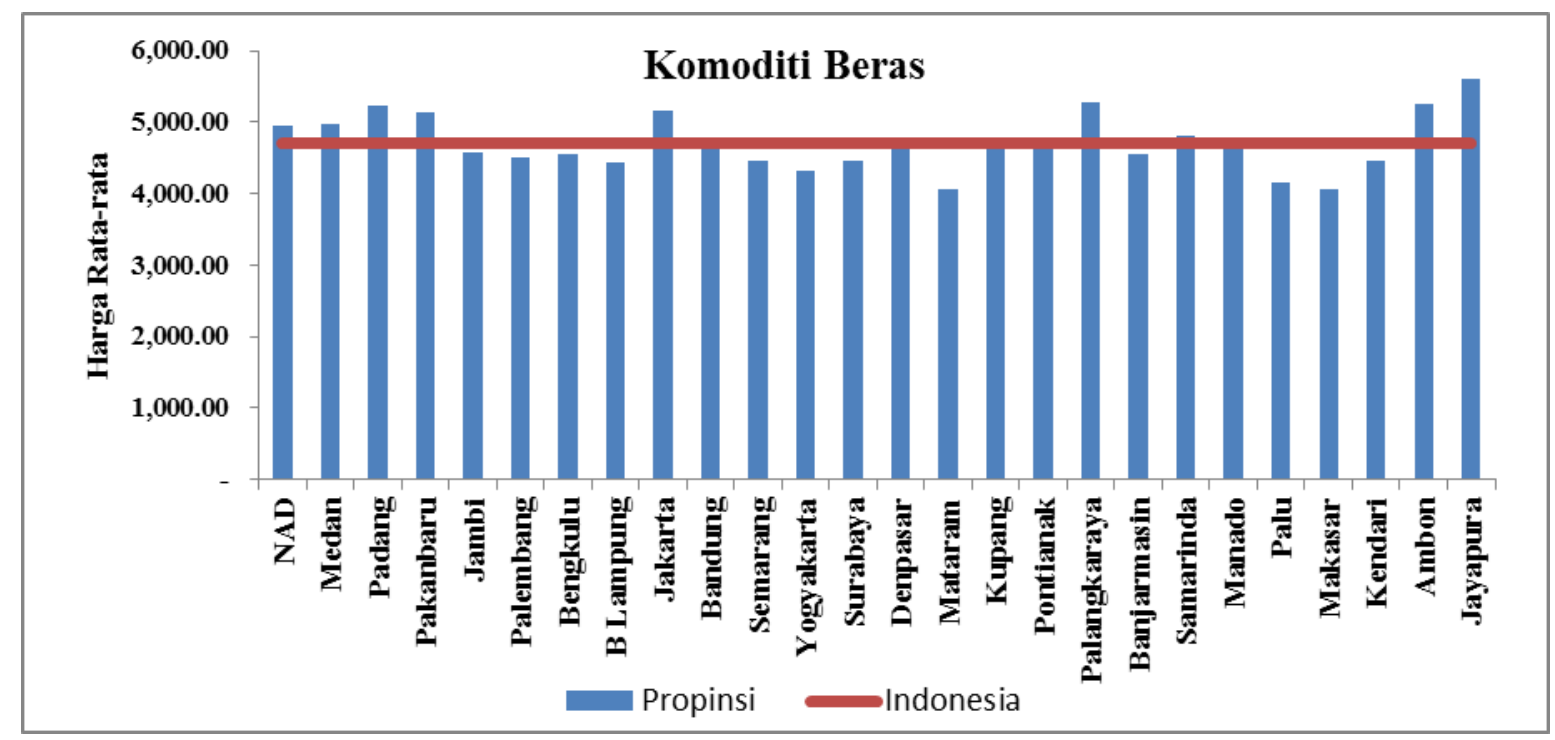

Gambar 3 Harga Rata-rata Beras antar Propinsi di Indonesia dari tahun 2002 - 2010

Pada komoditi minyak goreng harga rata-rata antar wilayah selalu berbeda-beda dimana harga minyak goreng tertinggi pada wilayah Kendari. Hal ini disebabkan oleh harga kopra di berbagai sentra produksi kelapa mengalami kekurangan stok, disamping itu juga kenaikan dipengaruhi karena adanya keterlambatan pengiriman dari luar daerah sementara permintaan pasar cukup besar.

Harga rata-rata minyak goreng pada tahun 2002 - 2010 terendah pada wilayah Kupang. Hal ini disebabkan adanya surplus stok minyak goreng di pasar, surplus ini terjadi karena masyarakat Kupang masih banyak menggunakan minyak curah (minyak kelapa) yang dimasak sendiri ataupun membeli. Jika dibandingkan dengan ratarata nasional, maka harga komoditi minyak goreng yang berada di atas ratarata nasional sebesar $34.62 \%$. Sedangkan harga komoditi minyak goreng yang berada di bawah rata-rata nasional sebesar $65.38 \%$ (Gambar 4). 


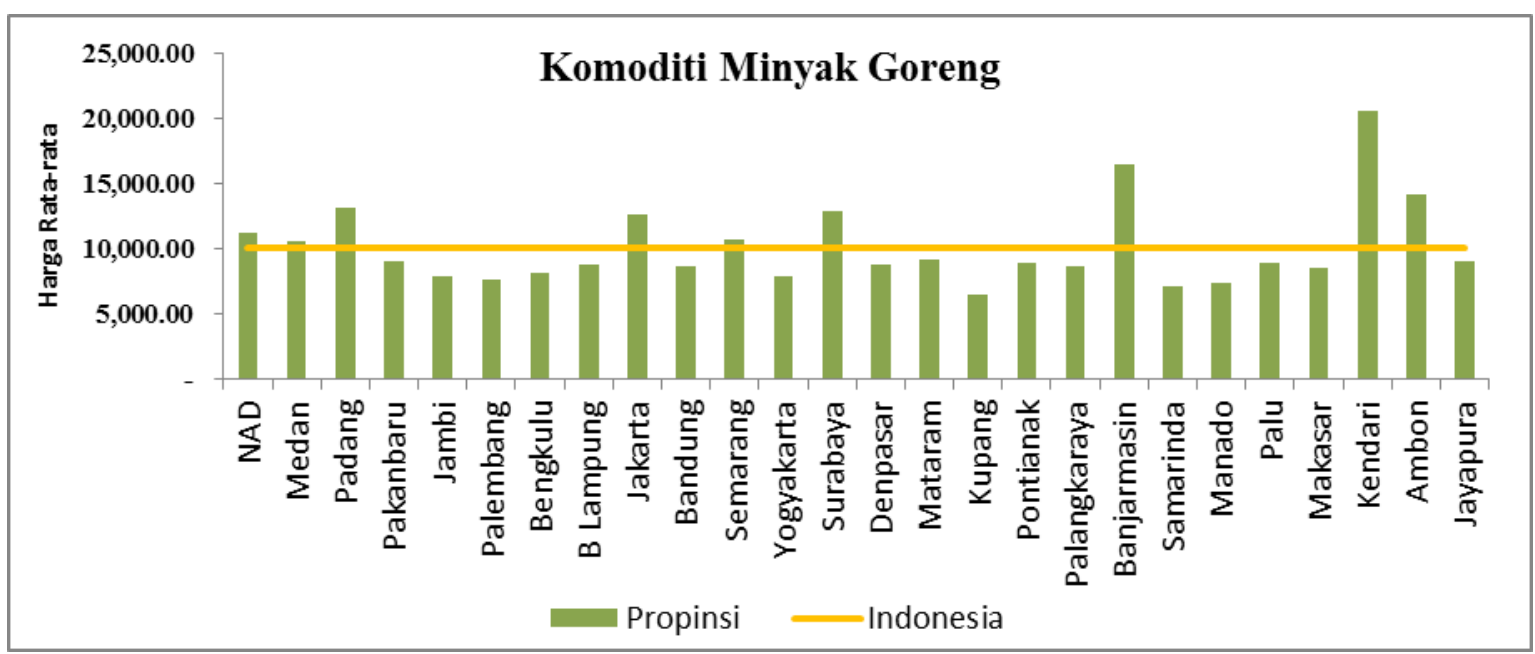

Gambar 4 Harga Rata-rata Minyak Goreng antar Propinsi di Indonesia dari tahun 2002 $-2010$

Pada komoditi gula pasir harga rata-rata antar wilayah selalu berbedabeda di setiap wilayahnya dimana harga minyak goreng tertinggi pada wilayah Jayapura. Tingginya harga yang terjadi di wilayah Jayapura disebabkan oleh permintaan meningkat sedangkan stok yang ada tidak mampu mencukupi kebutuhan konsumen, disamping itu juga adanya permainan yang dilakukan oleh para pedagang tengkulak dengan cara melakukan penimbunan yang bertujuan dapat mengendalikan harga.

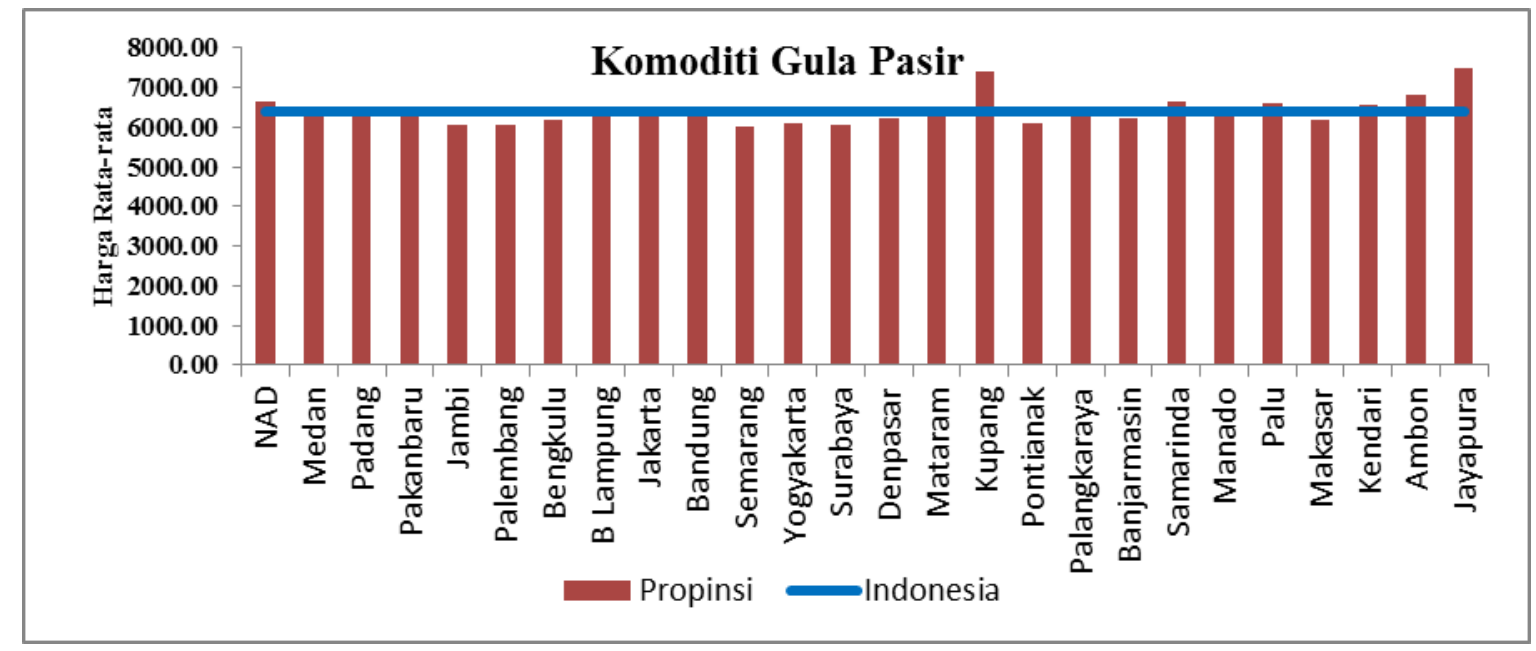

Gambar 5 Harga Rata-rata Gula Pasir antar Propinsi di Indonesia dari tahun 2002 2010

Rata-rata harga gula yang terendah terdapat di wilayah Semarang. Hal ini dipengaruhi karena adanya stok gula yang mampu memenuhi kebutuhan konsumen, dan disamping itu juga adanya kebijakan pemerintah yang mengatur mengenai harga dan ketentuan untuk mengimpor gula. Jika dibandingkan dengan rata-rata nasional, maka harga komoditi gula pasir yang berada di atas rata-rata nasional sebesar $38.46 \%$. Sedangkan harga komoditi gula pasir yang berada di bawah rata-rata nasional sebesar 61.54\% (Gambar 5).

Secara rata-rata rasio perubahan harga pangan pokok dari tahun 2002 2010 berada diatas tingkat inflasi, dimana tingkat inflasi rata-rata sebesar 8,07\%. Ini 
berarti bahwa ketiga komoditi pangan pokok sangat besar memberikan sumbangan terhadap tingkat inflasi. Ratarata rasio perubahan harga tertinggi pada komoditi gula pasir. Hal ini disebabkan karena pangsa produksi gula di dalam negeri hanya sekitar $56,25 \%$ dan selebihnya $43,75 \%$ berasal dari gula impor, baik berbentuk gula rafinasi maupun gula mentah yang kemudian diolah menjadi gula rafinasi. Masih tingginya ketergantungan Indonesia terhadap produksi gula negara lain, akibatnya harga gula pasir meningkat dan menyebabkan tingginya tingkat inflasi karena disebabkan kenaikan harga gula di pasaran internasional akibat perubahan cuaca yang tidak menentu, sehingga beberapa produsen gagal panen karena kemarau yang berkepanjangan. Begitu juga, konversi bahan bakar kendaraan yang berbahan baku gula menyebabkan persediaan gula internasional mengalami penurunan sedangkan saat ini stok gula yang dimiliki PTPN dan Rajawali Nusantara Indonesia tinggal 200 ribu ton, angkayang sangat minim untuk negara sebesar Indonesia.

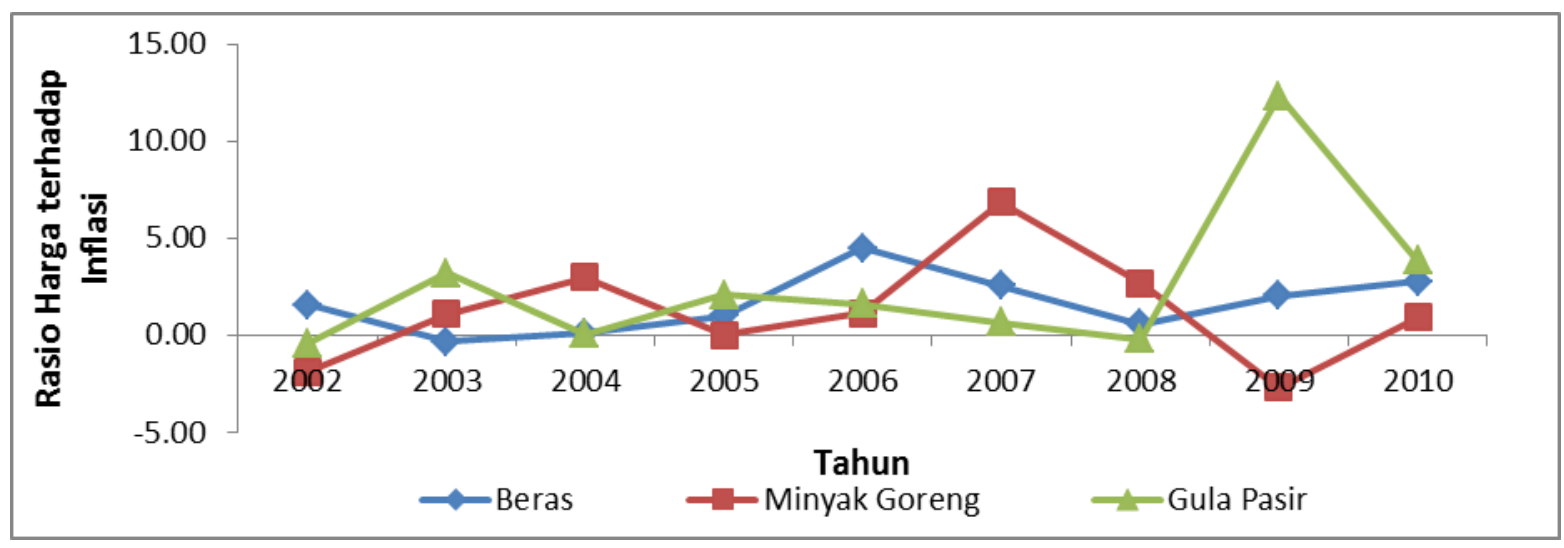

Gambar 6 Rasio Perubahan Harga Pangan Pokok terhadap Inflasi di Indonesia Periode Tahun $2002-2010$

Tingginya harga gula disebabkan oleh tren konsumsi gula nasional hingga saat ini cenderung meningkat dari 2,5 juta ton pada tahun 1990 menjadi 4 juta ton pada tahun 2009. Dari jumlah tersebut, sebagian besar gula digunakan oleh rumah tangga (78\%) dan selebihnya selebihnya digunakan oleh industri, seperti industri pengolahan susu, industri roti dan biskuit, industri kembang gula, industri kecap dan sirup, dan industri coklat.

Rata-rata rasio perubahan harga untuk komoditi minyak goreng lebih kecil bila dibandingkan dengan beras dan gula pasir. Hal ini disebabkan karena produksi CPO domestik yang saat ini telah mencapai lebih dari 10 juta ton per tahun atau terbesar kedua di dunia setelah Malaysia dengan pangsa pasarnya adalah sekitar 30\% dari produksi CPO di dunia.
Meskipun secara rata-rata rasio perubahan harga minyak goreng paling kecil dari komoditi beras dan gula pasir namun jika di lihat antar tahun perubahan harga minyak goreng yang paling tinggi yang terjadi,hal ini diduga karenapengaruh dari harga $\mathrm{CPO}$ (Crude $\mathrm{Palm} \mathrm{Oil}$ ) internasional yang mengalami kenaikan.

Rasio perubahan harga beras berada pada urutan ke dua setelah gula pasir. Trend meningkatnya harga beras memang tak lepas dari hukum permintaan dan penawaran barang. Indonesia sebagai negara Asia dengan konsumsi beras sangat tinggi yakni mencapai $139.15 \mathrm{~kg}$ per kapita per tahun. Padahal negara-negara Asia lainnya tak lebih dari $100 \mathrm{~kg}$ per kapita per tahun. Dengan demikian, total permintaan beras Indonesia menjadi sangat besar 
mengingat jumlah penduduknyalebih dari 237 juta jiwa maka kebutuhan beras nasional 34 juta ton .

Permintaan terhadap beras yang tinggi tersebut tidak diimbangi dengan peningkatan produksi beras yang memadai di dalam negeri. Pada saat ini jumlah permintaan dan penawaran beras di Indonesia relatif berimbang, dalam arti jumlah yang tersedia dan jumlah yang dikonsumsi berselisih tipis. Keadaan tersebut sangat riskan, karena apabila terjadi goncangan permintaan atau penawaran, harga beras akan mudah berfluktuasi. Disamping itu, cadangan beras untuk pengamanan ketersedian oleh Pemerintah dilakukan dengan kebijakan impor. Instrumen impor inilah yang digunakan dalam mengantisipasi perilaku pasar agar tidak terjadi tindakan-tindakan yang justru memperkeruh pasar seperti aksi-aksi spekulasi.

\section{Konvergensi Harga Pangan Pokok Antar Wilayah dan Antar Waktu}

Estimasi konvergensi harga pangan pokok dilakukan dengan menggunakan tiga komoditi pada variabel dependennya, yaitu komoditi beras, minyak goreng dan gula pasir. Perbandingan ini dilakukan sebagai upaya untuk melihat apakah ada perbedaan harga pangan pokok pada tiga komoditi tersebut. Tingginya harga ratarata dari suatu komoditi tersebut tidak secara otomatis akan menyebabkan tingginya perbedaan harga komoditi tersebut pada antar wilayah karena harga rata-rata dari suatu komoditi tersebut tinggi terjadi pada semua wilayah atau pada wilayah tertentu saja di Indonesia.

Proses konvergensi harga pangan pokok dapat dilihat dari koefisien parameter autoregressive dari variabel harga beras. Nilai dari koefisien dari $\mathrm{y}_{\mathrm{t}-1}$ yang kurang dari1 menunjukkan adanya proses konvergensi, sedangkan nilai yang lebih dari 1 menunjukkan bahwa harga beras antar wilayah persisten. Model data panel dinamis FD-GMM menunjukkan bahwa koefisien $\mathrm{y}_{\mathrm{t}-1}$ adalah 0,9457 dan signifikan pada level 5\%, artinya proses konvergensi harga beras terjadi di antar wilayah di Indonesia. Dengan kata lain, harga beras antar wilayah konvergen. Berdasarkan statistik uji Sargan, hipotesis nol bahwa variabel instrumen valid tidak ditolak, dengan pvalue 0,1707, artinya variabel instrumen yang digunakan valid. Uji konsistensi model dilakukan dengan melihat tingkat signifikansi $\mathrm{AB} m_{1}$ yang tidak signifikan pada tingkat level 5\% dan $\mathrm{AB} m_{2}$ yang tidak signifikan pada tingkat level 5\%, artinya ada korelasi serial atau model tidak konsisten.

Perhitungan konvergensi harga beras antar wilayah di Indonesia berbeda dengan penelitian yang dilakukan oleh Barrios et al. (2007) di Philipina bahwa terjadi proses divergen pada komoditi harga beras pada tahun 1990 - 2002 akibat adanya badai El Nino pada tahun 1998.

Adanya konvergensi harga beras antar wilayah di Indonesia karena produksi beras Indonesia cukup besar mencapai 62,09 juta ton pada tahun 2010 atau menduduki urutan ketiga di dunia setelah China dan India. Sementara tingkat produktivitas per hektar juga sangat baik mencapai 4,9 ton/ha, di atas produktivitas rata-rata negara Asia sebesar 4,2 ton/ha. Pada tahun 2010, produksi padi nasional mencapai 64,09 juta ton dimana kenaikan produksi terjadi karena peningkatan luas panen seluas 252 hektar $(17,5 \%)$ dan produktivitas naik sebesar 1,60 kuintal/hektar $(5,36 \%)$ yang sebagian besar disumbang oleh sentrasentra produksi di Pulau Jawa. Propinsi Jawa Barat merupakan penyumbang terbesar dengan porsi $17,3 \%$ diikuti Jawa Timur sebesar $16,6 \%$, Jawa Tengah $15,5 \%$, Sulawesi Selatan 6,3\%, Sumatera Utara 5,7\%, dan Sumatera Barat 3,4\% (BPS Indonesia 2010)

$$
\text { Estimasi konvergensi pangan }
$$
pokok dapat dilihat dari koefisien parameter autoregressive dari variabel harga minyak goreng. Nilai koefisien $\mathrm{y}_{\mathrm{t}-1}$ 
pada lag variabel dependen kurang dari satu, sehingga menghasilkan tingkat konvergensi yang positif. Tingkat konvergensi mencapai $31,97 \%$ berdasarkan hasil empiris koefisien $\mathrm{y}_{\mathrm{t}-1}$ sebesar 0,7263; mengindikasikan adanya konvergensi harga minyak goreng antar wilayah di Indonesia, dengan tingkat konvergensi sebesar 31,97\%. Berdasarkan statistik uji Sargan menunjukkan bahwa hipotesis nol variabel instrumen valid tidak ditolak. Sedangkan uji $m_{l}$ tidak signifikan sedangkan nilai $m_{2}$ signifikan juga sehingga menunjukkan bahwa ada serial correlation dan model tidak konsisten.

Tabel 2 Estimasi Konvergensi Harga Pangan Pokok Menggunakan Metode Data Panel Dinamis FD-GMM

\begin{tabular}{|c|c|c|c|c|}
\hline Komoditi & Parameters & Koefisien & SE & $P$-value \\
\hline \multirow{6}{*}{ Beras } & Harga $_{t-1}$ & 0,9457 & 0,0091 & 0,0000 \\
\hline & Implied $\lambda$ & 5,5829 & & \\
\hline & Wald-Test & 58510,38 & & 0,0000 \\
\hline & $\mathrm{AB}_{m l}$ & $-1,8735$ & & 0,0610 \\
\hline & $\mathrm{AB}_{m 2}$ & $-1,7353$ & & 0,0827 \\
\hline & Sargan Test & 25,8523 & & 0,1707 \\
\hline \multirow{6}{*}{$\begin{array}{l}\text { Minyak } \\
\text { Goreng }\end{array}$} & Harga $_{t-1}$ & 0,7263 & 0,0082 & 0,0000 \\
\hline & Implied $\lambda$ & 31,9792 & & \\
\hline & Wald-Test & 36361,74 & & 0,0000 \\
\hline & $\mathrm{AB}_{m l}$ & $-1,4498$ & & 0,1471 \\
\hline & $\mathrm{AB}_{m 2}$ & $-2,8404$ & & 0,0045 \\
\hline & Sargan Test & 25,8474 & & 0,1709 \\
\hline \multirow{6}{*}{ Gula Pasir } & Harga $_{t-1}$ & 0,8038 & 0,0195 & 0,0000 \\
\hline & Implied $\lambda$ & 21,8404 & & \\
\hline & Wald-Test & 32764,50 & & 0,0000 \\
\hline & $\mathrm{AB}_{m l}$ & $-3,7839$ & & 0,0002 \\
\hline & $\mathrm{AB}_{m 2}$ & $-0,1833$ & & 0,8545 \\
\hline & Sargan Test & 25,9159 & & 0,1686 \\
\hline
\end{tabular}

Tingkat konvergensi minyak goreng mencapai nilai yang cukup tinggi dibandingkan dengan tingkat konvergensi beras, sama juga yang dilakukan di Cina dimana komoditi yang konvergen adalah gabah, minyak goreng, unggas, ikan (Wan, 2005). Hal ini terjadi karena bila dilihat dari volumenya, konsumsi minyak goreng sawit Indonesia merupakan yang terbesar di dunia dengan laju pertumbuhan rata-rata mencapai $11,4 \%$ per tahun selama periode 1990-2007. Dengan tingkat konsumsi yang mencapai 2,8 juta ton per tahun, maka dibutuhkan 
sekitar 3,8 juta ton CPO sebagai bahan bakunya. Jumlah tersebut pada dasarnya masih dapat dipenuhi dari produksi CPO domestik yang saat ini telah mencapai lebih dari 10 juta ton per tahun atau terbesar kedua di dunia setelah Malaysia. Dengan porsi hanya sekitar $30 \%$ dari produksi $\mathrm{CPO}$, pengadaan bahan baku minyak goreng sawit dalam negeri pada dasarnya tidak menemui kendala yang berarti seiring dengan peningkatan luas areal tanaman kelapa sawit yang tersebar di 18 propinsi, yakni Nangro Aceh Darussalam, Sumatera Utara, Riau, Jambi, Sumatera Barat, Sumatera Selatan, Lampung, Bengkulu, Bangka Belitung, Kalimantan Barat, Kalimantan Selatan, Kalimantan Tengah, Kalimantan Timur, Sulawesi Selatan, Sulawesi Tengah, Sulawesi Tenggara, Jawa Barat dan Papua termasuk Irian Jaya Barat. Diantara wilayah tersebut, Riau (termasuk Kepulauan Riau) merupakan sentra produksi terbesar dengan luas lahan mencapai $23,5 \%$ dari total luas perkebunan kelapa sawit Indonesia yang saat ini mencapai 6.074.926 ha.Sejalan dengan peningkatan luas areal, produksi CPO Indonesia juga meningkat sangat signifikan dari 230 ribu ton pada Januari 1990 menjadi 1 juta ton pada November 2007. Sebagian besar produksi CPO berasal dari Sumatera Utara dengan kontribusi $50 \%$ dari total produksi CPO nasional.

Estimasi konvergensi harga gula pasir akan dibandingkan dengan konvergensi harga beras dan minyak goreng untuk melihat apakah dampak kebijakan pemerintah terhadap pangan pokok sudah berhasil atau belum (Tabel 3). Proses konvergensi terjadi pada komoditi gula pasir, yang ditunjukkan dengan nilai koefisien dari $\mathrm{y}_{\mathrm{t}-1}$ sebesar 0,8038 dan menghasilkan tingkat konvergensi 21,84\%. Berdasarkan statistik uji Sargan, hipotesis nol bahwa variabel instrumen valid tidak ditolak, dengan $P$-value 0,1686. Uji konsistensi model dilakukan dengan melihat tingkat signifikansi $\mathrm{AB} m_{l}$ yang signifikan pada tingkat level $5 \%$ dan $\mathrm{AB} m_{2}$ yang tidak signifikan pada tingkat level $5 \%$, artinya tidak ada korelasi serial pada model atau model konsisten. Dilihat dari tiga komoditi diatas ternyata tingkat konvergensi tertinggi pada komoditi minyak goreng, gula pasir lalu tingkat konvergensi terendah terjadi pada komoditi beras yang berarti kebijakan pemerintah di bidang pemberasan belum sepenuhny berhasil yang dilihat dari tingkat konvergensi beras hanya 5,59\%.

\section{Faktor-faktor yang Mempengaruhi Harga Pangan Pokok antar Wilayah dan antar Waktu di Indonesia}

Di antara kebutuhan pokok, beras, gula pasir dan minyak goreng merupakan komoditas yang posisinya sangat strategis dan karena itu pemerintah selalu berusaha agar harga kedua komoditas tersebut relatif stabil. Pengertian "stabil" tidaklah bersifat statis, tetapi dinamis yakni suatu kondisi dimana variabilitas harga antar waktu dan antar wilayah berada pada kisaran yang masih memungkinkan bagi stakeholder (produsen dan konsumen) untuk melakukan penyesuaian dalam jangka pendek. Bagi konsumen, determinan dari kemampuan untuk melakukan penyesuaian adalah daya beli; sedangkan bagi produsen determinannya adalah tingkat penerimaan yang cukup untuk menutup semua biaya variabel.

Estimasi harga pangan pokok melalui variabel harga beras, dimana faktor-faktor yang mempengaruhi harga beras dilakukan dengan menggunakan variabel independen jumlah produksi, Produk Domestik Regional Bruto (PDRB), jumlah penduduk dan panjang jalan. Model panel data dinamis yang terpilih untuk analisis perubahan harga beras adalah FD-GMM (Arellano and Bond) dengan p-value 0.0000. R-square sebesar 0.8881 artinya variasi variabel independen dapat menjelaskan $88.81 \%$ variasi harga beras, sedangkan $11.19 \%$ 
sisanya dijelaskan oleh variabel lainnya yang tidak ada dalam model (Tabel 8).

Harga beras antar wilayah dan antar waktu di Indonesia di pengaruhi oleh jumlah produksi dan panjang jalan secara negatif serta PDRB dan jumlah penduduk secara positif. Peningkatan jumlah produksi dan panjang jalan akan menurunkan harga beras tahun sedangkan meningkatnya PDRB dan jumlah penduduk akan meningkatkan harga beras.

Jumlah produksi mempengaruhi harga beras sebesar $0.27 \%$. Jika Jumlah produksi naik $1 \%$, maka harga beras akan turun sebesar $0.27 \%$. Hal senada terjadi pada panjang jalan yang mempengaruhi harga beras sebesar $0.17 \%$ secara negatif. Artinya jika panjang jalan bertambah $1 \%$ maka harga beras akan turun sebesar $0.17 \%$. Arah berbeda yang terjadi pada variabel PDRB dan jumlah penduduk dimana harga beras juga dipengaruhi oleh PDRB dan jumlah penduduk sebesar $0.20 \%$ dan $7.11 \%$. Jika tingkat PDRB naik $1 \%$ akan menyebabkan kenaikan harga beras sebesar $0,20 \%$. Jika jumlah penduduk naik 1\% akan menyebabkan kenaikan harga beras cukup tinggi sebesar $7.11 \%$. Tingginya kenaikan harga akibat kenaikan jumlah penduduk menandakan masih tingginya ketergantungan masyarakata pada komoditi beras meskipun jenis pasar untuk komoditi beras masih bersifat oligopoli. Hasil estimasi ini berbeda studi yang dilakukan oleh Syafa'at (2007), bahwa harga beras dipengaruhi oleh tiga variabel penjelas yakni harga pembelian pemerintah (HPP), stok beras Bulog dan harga beras di pasar internasional.

Tabel 3 Hasil Estimasi Faktor-faktor yang Mempengaruhi Harga Pangan Pokok dengan Model Panel Data Statis

\begin{tabular}{|c|c|c|c|c|}
\hline Periode & Veriable & Coefficients & Standard Error & Prob \\
\hline \multirow{8}{*}{ Beras } & Prod & -0.2720 & 0.0350 & 0.0000 \\
\hline & PDRB & 0.2027 & 0.0350 & 0.0000 \\
\hline & Pendk & 7.1128 & 0.0764 & 0.0000 \\
\hline & Jalan & -0.1717 & 0.0238 & 0.0000 \\
\hline & R-squared & 0.8881 & & \\
\hline & Ajusted R-squared & 0.8853 & & \\
\hline & F-Statistic & 320.68 & & \\
\hline & Prop & 0.0000 & & \\
\hline \multirow{8}{*}{$\begin{array}{l}\text { Minyak } \\
\text { Goreng }\end{array}$} & Prod & -0.0111 & 0.0016 & 0.0000 \\
\hline & PDRB & 0.4249 & 0.0907 & 0.0000 \\
\hline & Pendk & 8.4225 & 0.4248 & 0.0000 \\
\hline & Jalan & -0.0709 & 0.0203 & 0.0000 \\
\hline & R-squared & 0.7221 & & \\
\hline & Ajusted R-squared & 0.7252 & & \\
\hline & F-Statistic & 104.99 & & \\
\hline & Prop & 0.0000 & & \\
\hline \multirow{8}{*}{ Gula Pasir } & Prod & -0.1096 & 0.0308 & 0.0000 \\
\hline & PDRB & 0.2259 & 0.0483 & 0.0000 \\
\hline & Pendk & 8.8930 & 0.2134 & 0.0000 \\
\hline & Jalan & -0.0178 & 0.0342 & 0.6010 \\
\hline & R-squared & 0.7580 & & \\
\hline & Ajusted R-squared & 0.7520 & & \\
\hline & F-Statistic & 126.52 & & \\
\hline & Prop & 0.0000 & & \\
\hline
\end{tabular}

Estimasi faktor-faktor yang mempengaruhi harga pangan pokok melalui variabel harga minyak goreng dilakukan dengan menggunakan variabel independen jumlah produksi, Produk Domestik Regional Bruto (PDRB), 
jumlah penduduk dan panjang jalan. Model panel data dinamis yang terpilih untuk analisis perubahan harga minyak goreng adalah FD-GMM dengan p-value 0,0000 . R-square sebesar 0,7221 artinya variasi variabel independen dapat menjelaskan $72.21 \%$ variasi harga minyak goreng, sedangkan $27.79 \%$ sisanya dijelaskan oleh variabel lainnya yang tidak ada dalam model (Tabel 8).

Harga minyak goreng antar wilayah di Indonesia di pengaruhi oleh PDRB dan jumlah penduduk secara positif. Sedangkan jumlah produksi dan panjang jalan mempengaruhi harga minyak goreng secara negatif. Peningkatan PDRB dan jumlah penduduk dapat meningkatkan harga minyak goreng sebesar $0.42 \%$ dan $8.42 \%$. Jika PDRB naik $1 \%$, maka harga minyak goreng akan naik sebesar $0.42 \%$ dan Jika jumlah penduduk naik $1 \%$, maka harga minyak goreng akan naik sebesar $8.42 \%$. Tingginya permintaan akibat kenaikan jumlah penduduk menyebabkan meningkatnya harga minyak goreng. Selain karena jumlah penduduk, tingginya harga minyak goreng juga dipicu oleh bentuk pasar dari komoditi minyak goreng yang bersifat olgopoli.

Peningkatan jumlah produksi dan panjang jalan dapat menurunkan harga minyak goreng sebesar $0.01 \%$ dan $0.07 \%$. Jika jumlah produksi naik $1 \%$, maka harga minyak goreng akan turun sebesar $0.01 \%$. Jika panjang jalan bertambah $1 \%$, maka harga minyak goreng akan turun sebesar $0.07 \%$.

Berbeda dengan penelitian yang dilakukan oleh Prastowo et al. (2008), bahwa harga minyak goreng dipengaruhi oleh harga minyak goreng tahun sebelumnya dan harga CPO dunia, jumlah produksi dan dummy BULOG yang bernilai negatif dan signifikan. Hal ini menandakan pada saat BULOG berperan aktif dalam pengaturan stok dan distribusi minyak goreng hingga tahun 1998, harga eceran minyak goreng cenderung lebih rendah dan stabil dibandingkan setelah 1998.

Estimasi faktor-faktor yang mempengaruhi pangan pokok melalui variabel harga gula pasir dilakukan dengan menggunakan variabel independen jumlah produksi, Produk Domestik Regional Bruto (PDRB), jumlah penduduk dan panjang jalan. Model panel data dinamis yang terpilih untuk analisis perubahan harga gula pasir adalah FD-GMM (Arellano and Bond) dengan p-value 0.0000. R-square sebesar 0.7580 artinya variasi variabel independen dapat menjelaskan $75.80 \%$ variasi harga gula pasir, sedangkan $24.20 \%$ sisanya dijelaskan oleh variabel lainnya yang tidak ada dalam model (Tabel 8).

Harga gula pasir antar wilayah di Indonesia di pengaruhi oleh PDRB dan jumlah penduduk secara positif serta jumlah produksi secara negatif. Peningkatan PDRB dan jumlah penduduk dapat meningkatkan harga gula pasir. Tetapi sebaliknya peningkatan jumlah produksi gula akan menyebabkan harga gula pasir mengalami penurunan.

PDRB mempengaruhi harga gula pasir sebesar 0.22. Jika harga gula pasir tahun sebelumnya naik $1 \%$, maka harga gula pasir akan naik sebesar $0.22 \%$. Jumlah penduduk mempengaruhi harga gula pasir sebesar $8.89 \%$. Tingginya pengaruh jumlah penduduk terhadap harga gula pasir karena pasar dari gula pasir itu sendiri yang bersifat oligopoli. Jika jumlah penduduk naik $1 \%$ maka harga gula pasir akan naik sebesar $8.89 \%$. Jumlah produksi juga mempengaruhi harga gula pasir sebesar $0.10 \%$. Jika jumlah produksi naik 1\% maka harga gula pasir akan turun sebesar $0.10 \%$.

Harga gula di tingkat konsumen juga sangat dipengaruhi oleh harga gula di pasar internasional, dummy BULOG dan dummy untuk penerapan pembatasan impor gula sejak September 2002. Hal ini diduga karena tren produksi dalam negeri semakin menurun, terutama setelah krisis 
seiring dengan menurunnya kinerja dan jumlah pabrik gula yang beroperasi. Sementara itu, tren kebutuhan gula meningkat seiring dengan pertambahan jumlah penduduk. Jumlah produksi tidak berpengaruh, karena pemenuhan kebutuhan gula dalam negeri pada akhirnya lebih banyak mengandalkan pada gula impor (Prastowo et al. 2008).

\section{KESIMPULAN}

Dinamika harga rata-rata tertinggi antar wilayah dari tahun 2002-2010 untuk komoditi beras dan gula pasir berada di wilayah Jayapura, minyak goreng di wilayah Kendari. Harga ratarata terendah dari tahun 2002-2010 untuk komoditi beras di wilayah Sulawesi Selatan, minyak goreng dan gula pasir di wilayah Semarang. Dinamika rasio perubahan harga rata-rata tertinggi antar waktu dari tahun 2002-2010 untuk komoditi pangan pokok adalah gula pasir, sedangkan rasio perubahan harga ratarata terendah adalah minyak goreng.

Konvergensi terjadi pada semua komoditi, dengan tingkat konvergensi tertinggi terdapat pada komoditi minyak goreng dan terendah pada komoditi beras. Faktor-faktor yang berpengaruh terhadap perubahan harga pangan pokok adalah jumlah produksi, Produk Domestik Regional Bruto (PDRB) dan jumlah penduduk.

\section{DAFTAR PUSTAKA}

Barro, R. and Sala-i-Martin, X. (1991), "Convergence across states and regions", Brookings Paper on Economic Activity, Vol. 1, pp. 107-82.

Borensztein, E., Khan, M.S., Reinhart, C.M., and Wickham, P. (1994). The Behavior of Non-oil Commodity Prices. Occasional Paper No.112, Internation Monetary Fund, Washington D.C. Chambers, M.J. and Bailey, R.E. (1996). A theory of commodity price fluctuations. The Journal of
Political Economy, Vol. 104, No. 5, hal. 924-957.

Dawe, D. (2001). How Far Down the Path to Free Trade? The Importance of Rice Price Stabilization in Developing Asia. Food Policy, Vol. 26, hal. 163175.

Deaton, A. and Laroque, G. (1992). On the behavior of commodity prices. Review of Economic Studies, No. 59, hal. 1-23.

Hasan, M.F. 2008. "Menghindari Krisis Pangan Global". Majalah Investor Daily.

Loveridge, S. 1991. "Marketing in Rwanda - imports and infrastructure." Food Policy 16:95-104.

Minten, B. and S. Kyle. 1999. "The effect of distance and road quality on food collection, marketing margins, and traders' wages: Evidence from the former Zaire." Journal of Development Economics 60: 467-495.

Prastowo, Nugroho Joko, 2008, Pengaruh Distribusi dalam Pembentukan Harga Komoditas dan Implikasinya terhadap Inflasi, Working Paper, Bank Indonesia

Quah, D. 1995. Empirics for Economic Growth and Convergence. Centre forEconomic Performance Discussion Paper 253:10-23.

Raharja dan Mandala, 2002. Teori Ekonomi Mikro : Suatu Pengantar. Fakultas Ekonomi Universitas Indonesia, Jakarta.

Salvatore, D. 1996, Internasional Economics, New Jersey : Prentice Hall Inc.

Siregar, H. 2009. Dinamika Harga Pangan, BBM, Inflasi serta Kemiskinan, dan Implikasinya bagi Ketahanan Pangan. IPB Pres. Bogor

Soekartawi, 2002. Prinsip Dasar Ekonomi Pertanian : Teori dan 
Aplikasi Edisi Revisi 2002. RajaGrafindo Persada. Jakarta

Sulastiri. Y. P. 2008. Diversifikasi Konsumsi Pangan Pokok Berbasis Potensi Lokal Dalam Mewujudkan Ketahanan Pangan Rumahtangga Pedesaan Di Kecamatan Semin Kabupaten Gunung Kidul

Suparmoko, M. 1997. Pengantar Ekonomika Mikro (Edisi Kedua). BPFE, Yogyakarta

Syafa'at, B. 2007. Studi Dinamika Produksi Padi Tahun 2001 dan Identifikasi Faktor Penyebabnya. Puslitbang Sosial Ekonomi Pertanian bekerjasama dengan
ARMP II (Agriculture Research Management Project). Badan Litbang Pertanian.

Timmer, 2008. Productivity Level Database: International Comparisons of Output, Inputs and Productivity at the Industry Level. Research Memorandum GD-104,

Groningen Growth and Development Centre, University of Groningen

Tomek, W. G. (2000). Commodity Prices Revisited. Staff Paper 2000-05, Department of Applied Economics and Management, Cornell University, New York. 